Doctor of Historical Sciences (Dr. Hab. in History), Professor at the Department of History of Ukrainians in the World, T.Shevchenko National University of Kyiv (Kyiv, Ukraine), ovd@ua.fm

Valeri Kononenko

Doctor of Historical Sciences (Dr. Hab. in History), Docent, Associate Professor at the Department of Legal Sciences and Philosophy,

Vinnytsia M.Kotsiubynskyi State Pedagogical University

(Vinnytsia, Ukraine), valeriy_kononenko@ukr.net

\title{
NATIONAL EDUCATION IN A CONTEXT OF PRESERVING IDENTITY OF JEWISH COMMUNITIES OF PODILLIA
}

The purpose of the work is to determine the role of the national education of Jewish communities of Podillia in the preservation of the original culture of the Jews of the region. The authors study the place of the traditional education in preserving national identity of the Jewish communities of Podillia in comparison with the functioning of the national education of Jews in Ukraine. The methodology of the research is based on the use of comparative-historical, statistical, structural-functional, terminological methods taking into account the axiological (value) approach, which allowed to consider Jewish national education as a self-sufficient formation with a system of certain values that are important for the functioning of the national culture of the Jews. The scientific novelty is to substantiate Jewish national education as a cultural phenomenon, which contributed to the existence of the original culture of Jewish communities in the region during a long historical period. The article claims that one of the most powerful Jewish regional communities of Eastern Europe was formed on the territory of the region, which represented the subethnos of Jewish people-Ashkenazi. The Jews of Podillia, who lived in a discriminatory policy aimed at destroying the foundations of national life, managed to preserve their national identity and national culture. The article states that before the inclusion of the territory of Podillia in the Russian Empire, the traditional national system of education was here. It was based on the strict connection of studying with the religion and traditions of the Jewish people. For centuries, this Jewish national community preserved its national identity and avoided complete assimilation. Along with religion, education traditionally protected the Jews from losing their national-cultural life and national peculiarities of the life of community. The authorities of the Russian Empire tried to encourage Jews to receive general state education, hoping to overcome the isolation of Jews and form loyalty to the Empire in this way. However, the vast majority of Jews in Podillia traditionally continued to study in Cheders and Talmud Torahs. The Soviet government has taken the course of destroying religious education institutions and displacing Hebrew as a language of instruction. At the same time, she considered for a while Jewish national schools with the Yiddish language of instruction as an element of Sovietization of Jews. However, since the late 1940s, it introduced the course for assimilation of Jews and the destruction of elements of national life. New opportunities for the reconstruction of the national education of the Jews of Podillia appeared with the proclamation of Ukraine's independence. National education and religion has become the main elements of preserving the national life of Jews at the present stage. Jewish national education is a certain cultural and social phenomenon that has helped the Jews for a long time in conditions of the absence of the state to 
preserve the integrity of their people. The education that was inextricably linked with religion played a major role in preserving the identity and national culture of the Jewish communities in Podillia.

Keywords: Jews, Podillia, national education, originality, national culture.

The population of Podillia has long been presented, besides the Ukrainians, inhabitants of other peoples. The history of the region was formed not only by the Ukrainians but also by the Jews, the Poles, the Russians and representatives of other nations. One of the most powerful Jewish regional communities of Eastern Europe was formed on the territory of the region, which represented the subethnos of Jewish people - Ashkenazi. This national minority is not native or autochthonous for Podillia, since its ethnogenesis is not related to the territory of the region, and the first Jewish settlers who came from Western Europe appeared here in the $14^{\text {th }}$ century.

The urgency of the article is determined by the fact that the Jews of Podillia, who lived in a discriminatory policy aimed at destroying the foundations of national life, managed to preserve their national identity and national culture. Neither the Russian Empire nor the USSR could completely destroy Jewish national community.

The role of national education in preserving ethnic identity and preserving the original culture of the Jewish population of Podillia has been actively explored only recently. Only modern Ukrainian and foreign scientific literature represent historiography of the subject of research. In fact, there are no qualifying scientific researches and monographic studies of this issue. The most fully studied issue of the status of Jewish national culture in the Soviet period. Among studies of such a plan are allocated researches A.Shternshis ${ }^{1}$, Z.Gitelman ${ }^{2}$, L.Yakubova ${ }^{3}$, L.Finberh, L.Liubchenko ${ }^{4}$, E.Getmansky ${ }^{5}$, M.Zerkal ${ }^{6}$. Issues of the Jewish national education were studied in the writings of Z.Halevy ${ }^{7}$, E.Schulman ${ }^{8}$, A.Komarnitskyi ${ }^{9}$, F.Vynokurova ${ }^{10}$.

1 Shternshis A. Soviet and Kosher. Jewish Popular Culture in the Soviet Union, 1923-1939. Bloomington and Indianapolis, 2006. - $281 \mathrm{p}$.

${ }^{2}$ Gitelman Z. A Century of Ambivalence: The Jews of Russia and the Soviet Union, 1881 to the Present. - Bloomington and Indianapolis, 2001. - 297 p.

${ }_{3}$ Якубова Л. Етнічні меншини в суспільно-політичному та культурному житті УСРР: 20-і перша половина 30-х рр. XX ст. - К., 2006. - 507 с.

${ }_{4}^{4}$ Фінберг Л., Любченко Л. Нариси з історії та культури евреїв України. - К., 2008. - 440 с.

5 Гетлманский Э. Еврейское образование в Российской империи // Заметки по еврейской истории. - 2015. - №11/12 (188) [Електронний ресурc]: http://www.berkovich-zametki.com/2015/ Zametki/Nomer11_12/Getmansky1.php

6 Зеркаль М. Освіта національних меншин України (1990-2000-ні рр.) // Український історичний журнал. - 2013. - №2. - С.121-135.

${ }^{7}$ Halevy Z. Jewish Schools under Czarism and Communism: A Struggle for Cultural Identity. New York, 1976. - 298 p.

8 Schulman E. A History of Jewish Education in the Soviet Union. - New York, 1971. - 184 p.

9 Комарніцький $O$. Єврейська національна школа в містечках Правобережної України 1917-1918 pp. // Освіта, наука і культура на Поділлі. - Т.3. - Кам'янець-Подільський, 2003. - C.139-149.

${ }_{10}$ Винокурова Ф. Національне життя еврейської спільноти на окупованій території 
The purpose of the study is to investigate the national education as a factor of preservation of self-identification and national culture of Jewish population of the region since the formation of the first national communities before the World War II. The purpose of the research determines the task of the article: to study the historiography of this question, to identify the peculiarities of the national education of the Jews of Podillia, to characterize forms of national education in different historical periods, to define the role of national education in the preserved national culture of the Jews of the region.

Jewish national education is a certain cultural and social phenomenon that has helped the Jews for a long time in conditions of the absence of the state to preserve the integrity of their people. The education that was inextricably linked with religion, played a major role in preserving the identity and national culture of the Jewish communities in Podillia. The system of traditional education of Jews, built primarily in the education of religiosity and loyalty to the traditions and customs of the people, was an important factor in the development of the Jewish community.

In fact, until the middle of the $19^{\text {th }}$ century the majority of Jewish children in Podillia received education in traditional non-state Jewish educational institutions: Cheders, Talmud Torahs, and Yeshivas. Cheder was a Jewish elementary paid private religious school for boys that existed in Ukraine practically until the early 1920s. Talmud Torah was a Jewish religious school, which existed at the expense of the community and in which, unlike the Cheder, boys were mostly from poor families. Yeshiva (Ishiva) was a Jewish institution of higher learning, where the Oral Law is studied, mostly Talmud. Yeshivas continue their work in Ukraine and at the present stage. Zvi Gitelman believes that "the Jews felt keenly the need to protect themselves and preserve their values, as had Jews in Western Europe in the Middle Ages. Therefore Jews developed a complex network of institutions to take care of their own and to guard their cherished values and beliefs" ${ }^{11}$.

These traditional educational institutions functioned in the PolishLithuanian Commonwealth and later in the Russian Empire. They acted semi-legally in the Russian Empire and only at the end of the $19^{\text {th }}$ century were legalized. Their main feature was that they functioned on a religious basis. The religious nature of learning provided for the preservation of not only religious norms, but also the existence of the Jewish people in a predominant non-Jewish society. This, in turn, contributed to the preservation of traditional national culture. In addition, the preservation of traditional religion and Hebrew provided the connection of scattered in different countries of the Jewish national minorities as a single people.

The Regulation on the Jews of 1804 invited Jews to send their children to schools of the empire, but allowed them to preserve their own expense traditional

Вінницької області, що входила до складу Трансністрії: Огляд архівних джерел // Друга світова війна і доля народів України: Мат. Всеукр. наук. конф. (Київ, 23-24 червня 2005 р.). - К., 2005. - C.156-164.

11 Gitelman Z. A Century of Ambivalence: The Jews of Russia and the Soviet Union, 1881 to the Present. - P.28. 
schools. Condition - teaching one of the languages: Russian, Polish or German ${ }^{12}$. However, this reform laid the foundation for the emergence of a new Jewish pro-imperial intelligentsia, which in the future would have to lead the movement among Jews for secular education.

Traditional national education existed through the support of Jewish self-government - Qahal. During the reign of the Emperor Nicholas I there was an attack on the traditional foundations of the Jewish way of life. Qahal was forbidden in 1844 . The reform of the system of national education was one of the most "liberal" reforms in relation to Jews during the days of Emperor Nicholas I. All measures of power were directed, first of all, to the assimilation of Jews. The new system of state education for Jews was aimed at transforming the Jews of the empire into an analogue of the German Jews. They should become loyal subjects, get rid of religious fanaticism, engage in "useful" activities and should be integrated into the economic and social life of society $^{13}$.

At this time (1847) that the first state Jewish schools were founded, based on the all-Russian principles of organization of education. However, they did not gain popularity among the Jews. Jewish families were cautious to general education, because they did not allow them to adhere to their religious beliefs and customs.

Jewish families have been wary of general secular education because of their inability to follow their religious beliefs and customs. "Jews who generally respect education, precisely because of religious prejudices and opposition 'Teachers of the Talmud' did not send their children to these educational institutions or sent them there for a short time", - A.Alekseyev wrote in $1868^{14}$.

Attempts for reforms in the system of Jewish national education became possible because of the spread the Haskalah in the Russian Empire from the $19^{\text {th }}$ century. This international educational movement advocated for overcoming cultural and religious isolation, involving Jews in secular education, which, according to the leaders of the movement, would help integrate Jews into society and improve the situation of the Jewish population. However, in attempts to change the system of national education, Conservative Judaism and Hasidism showed a common opposition, since they believed that involving Jews into the state education system would promote assimilation processes among them (which was directed by the authorities). However, the shoots of assimilation have already come down. The Minister of Public Education of the Russian Empire S.Uvarov wrote that "a consoling conviction has been acquired that there are still quite a few young people among the educated and who can use the place of teachers in prospective Jewish schools"15.

12 Миллер А. Империя Романовых и национализм: Эссе по методологии исторического исследования. - Москва, 2006. - С.108.

${ }_{13}$ Там же. - C.114.

14 Алексеев А. Общественная жизнь евреев, их нравы, обычаи и предрассудки, с приложением биографии автора. - Новгород, 1868. - С.26.

15 Миллер А. Империя Романовых и национализм: Эссе по методологии исторического исследования. - С.115. 
It was difficult to overcome the resistance of the conservative Jewish community. In 1857, in the Podillia province of the Russian Empire, there were only 10 state Jewish schools (230 students), but acted 161 private Jewish schools: one Talmud Torah (50 students) and 160 Cheders (2775 students) ${ }^{16}$. The vast majority of children studied in private schools, but their number could not provide all Jewish children with education.

During the reign of the Emperor Alexander II, the civil rights of Jews were broadened, and the authorities refused to apply tough, repressive methods of solving the "Jewish question". However, it focusing their activities on reforming the educational system as a traditional element of national culture the Jews. There was so liberalized legislation concerning the Jews of the Russian Empire in $1856-1863$.

After the military reform of 1874 , even the conservative Jews began sending their children to secular secondary and higher educational institutions for the sake of reducing their service life, while Jewish youth began to enter universities more actively, since the diploma in higher education opened up the possibility for Jews to settle outside the Pale of Settlement.

In accordance with the "Regulations on Elementary Schools" issued during the period of the reforms of Alexander II in 1874, four state Jewish elementary schools were formed in Podillia. The government was compelled to give in and the decree of 1879 legitimized the existence of traditional Jewish schools, but the decree of 1893 fixed exclusively the religious status of schools ${ }^{17}$. However, at the same time after the reforms of the 1860s and 70s, in addition to state Jewish educational institutions, private male and female schools were established by the Government's permission.

On May 3, 1882, "Provisional Rules" imposed significant restrictions on the development of the national life of Jews, and the system of education of Jewish communities was tied to the zone of residence and the corresponding quota for studying at educational institutions. Because in the Pale of Settlement had a quota for studying Jewish youth at higher educational institutions so the vast majority of Jewish children in Podillia continued to receive Jewish traditional education.

This system of state Jewish educational institutions was preserved in the beginning of the twentieth century. In 1905 in the region the number of educational institutions in general, increased to 2157 but there remained only four state Jewish schools ${ }^{18}$. Because of this reason significant part of Jewish children studied either in private schools or in general public schools. For example, in 1910, there were 18 Jewish schools (Cheders) in Proskuriv. Jewish children also could choose from five Jewish colleges: three female gymnasiums, one male college for artisans, one coed college, and a Talmud Torah ${ }^{19}$.

16 Памятная книжка Подольской губернии на 1859 г. - Каменец-Подольский, 1859. - С.119.

17 Шитюк М.М., Щукін В.В. Єврейське населення Херсонської губернії в XIX - на початку ХХ ст. - Миколаїв, 2008. - С.130.

18 Обзор Подольской губернии за 1904 г.: Приложение к всеподданейшему отчету губернатора Подол. губ. стат. комитета. - Каменец-Подольский, 1905. - С.134-135.

${ }_{19}$ Voskoboynik D. The History of Jews in Proskurov, Ukraine. - Schenectady, 2002. - P.9. 
Despite the existence of private educational institutions of a more secular nature, the policy of assimilation of Jewish population remained unchanged. Before the World War I there were Jewish private secondary schools possessing the rights of governmental gymnasiums. In 1917, such educational institutions in Podillia existed in Proskuriv, Vinnytsia, Zhmerynka, Haisyn and MohylivPodilskyi ${ }^{20}$. In such educational institutions, the focus was on general subjects, and the teaching was conducted in Russian.

New perspectives for the development of national education began in 1917, after the February bourgeois-democratic revolution in the Russian Empire and the October Bolshevik coup of. Ukraine, which itself struggled for independence, was loyal to the realization by Jews their rights to have national-cultural autonomy. The development of national education was facilitated by the decrees of the Central Council and the Directory (1917-1920). On December 2, 1917, the Ukrainian Central Council approved the Law of the "Establishment of Jewish Public Councils" for the administrating of all Jewish affairs and institutions and holding on the elections to these councils. On January 9, 1918, the Law on National-Personal Autonomy was signed which provided for the right to organize their national life through self-government, the development of national culture and education.

Trying to stop the process of Russification through education, the authorities of the Ukrainian People's Republic resumed teaching in his native language from the school year 1918-1919 of all primary Jewish schools. However, during the period of the Ukrainian People's Republic in Podillia, the traditional system of Jewish education continued mainly through the cheders, talmud torahs and yeshivas. B.Pinkus notes that in 1918 in the Ukraine there were 270,000 Jewish children aged seven to eleven, 96,000 of whom were in secular schools, both Jewish and non-Jewish, while 174,000 children were apparently in cheders ${ }^{21}$. These educational institutions made up an overwhelming majority and were not financed by the authorities. At the same time, the system of secondary schools also developed. By the middle of 1918, there were 16 of them in Podillia ${ }^{22}$.

During the time of the Ukrainian Revolution and during a military confrontation with Bolshevik Russia, the Ukrainian side made significant steps that were aimed at developing the national-cultural sphere of the Jewish minority. As a result, the number of Jewish educational institutions in the Ukraine during the years 1917-1920 continued to grow.

The task of preserving and spreading the Jewish language and culture was taken care of by the cultural and educational society "Tarbut". The Society supported the Jewish People's Universities of Kyiv and Odesa, opened teacher courses, professional and evening schools, kindergartens, Saturday courses and clubs ${ }^{23}$.

20 Обзор Подольской губернии за 1904 г. ... - C.297.

${ }_{21}$ Pinkus B. The Jews of the Soviet Union: the history of a national minority. - Cambridge, 1988. - P.107.

${ }_{22}$ Комарніцький $O$. Єврейська національна школа в містечках Правобережної України 1917-1918 pp. - С.142.

23 Доценко В. Єврейський національний культурно-релігійний громадський рух в Україні в 1920-ті роки // Грані. - 2014. - №12. - С.121. 
The "Kultura-Liga", which was founded in Kyiv in January 1918, was of great importance for the development of the education of Jews during this period. The education Department of the Ministry of Jewish Affairs administered the Kultura-Liga, which supervised Jewish secular schools in Yiddish ${ }^{24}$. This organization, which in fact served as the Ministry of Education of Jews, until 1920 opened on the territory of Ukraine 283 educational institutions. She took care of children's homes, schools, gymnasiums, libraries and other Jewish institutions ${ }^{25}$. This organization created the Jewish People's University, which became the first Jewish educational establishment in the territory of the former Russian Empire. On her initiative, in the autumn of 1918, a department of Jewish culture was opened at the University of Kamianets-Podilskyi.

Significant changes in the system of traditional Jewish education and upbringing took place after the establishment of Soviet power in Ukraine. However, unlike the Ukrainian one, the Soviet authorities, through education of national minorities, tried to increase the number of their supporters. Nevertheless, a unified ramified network of secular educational institutions was created throughout the country. With the approval of Soviet power on the territory of Ukraine, all schools with the language of instruction in the Yiddish of the society "Tarbut" and "Kultura-Liga" were included in the Soviet system of the Yiddish secular schools ${ }^{26}$.

After 1921, traditional Jewish educational institutions were closed as educational institutions of a religious type. Some of them continued to operate illegally before the beginning of the period of the political terror of 1937-1938.

The revival of Jewish national education was facilitated by the proclamation of the course on "korenizatsiia" ("ukrainizatsiia" in Ukraine) by XII Congress of the Russian Communist Party (Bolsheviks). At this time, a new system of Jewish education was also developed. In 1926, there were 432 Jewish schools in the Ukrainian SSR, and in the 1930s there were $786^{27}$. L.Hrynevych notes that the existence of an extensive network of Jewish educational institutions was at that time a unique phenomenon in world practice, and this fact was used very actively by the Bolsheviks to promote the advantages of the Soviet sys$t^{2} \mathrm{~m}^{28}$. Hebrew as a language related to religion was ousted from the state system of education in the early 1920s and replaced by Yiddish. A.Shternshis notes that "Yiddish schools existed only at the elementary level, and there were no possibilities for higher or professional education in Yiddish (with the exception of a few vocational schools)" ${ }^{29}$. However, in the mid of 1920 s, more

${ }_{24}$ Schulman E. A History of Jewish Education in the Soviet Union. - P.41.

${ }_{25}$ Книга о русском еврействе: 1917-1967 / Под ред. Я.Г.Фрумкина, Г.Я.Аронсона, А.А.Гольденвейзера. - Нью-Йорк, 1968. - С.234.

${ }^{26}$ Schulman E. A History of Jewish Education in the Soviet Union. - P.44-45.

27 Якубова Л. Етнічні меншини в суспільно-політичному та культурному житті УСРР: 20-і - перша половина 30-х pp. XX ст. - С.415.

28 Гриневич Л. Єврейське національно-культурне відродження 1920-х - 1930-х рр. в УСРР у «прокрустовому ложі» більшовицької ідеології // Проблеми історії України: факти, судження, пошуки. - Вип.12. - К., 2004. - С.228.

${ }_{29}$ Shternshis A. Soviet and Kosher: Jewish Popular Culture in the Soviet Union, 1923-1939. - P.XVI. 
than 38000 Jewish children did not go to Soviet national schools at all, preferring illegal cheders ${ }^{30}$.

At the same time, during this period there was a great desire of Jews to be well educated. Taking advantage of the abolition of quotas and restrictions, they tried to get secondary and higher education. The aspiration of Jews to higher education has contributed to the fact that this national minority had one of the highest general educational levels in comparison with other peoples in Ukrainian SSR. For example, in the academic year 1927-1928 58,9\% of Ukrainians entered the higher educational institutions of the republic, $22 \%$ of Jews and $14,7 \%$ of Russians, while the number of Jews by the 1926 census in the Ukrainian SSR made up 5,43\% of the population ${ }^{31}$. V.Konstantinov notes that in the 1920 's and 1930 's literacy rate increased of all the peoples of the USSR. However, the level of literacy among Jewish men was the highest compared to other nationalities, and among women was second only to the Germans, Estonians and Finns, whose vast majority lived in cities $^{32}$.

A system of Jewish national professional and higher education institutions was also created. In 1931 in the Ukrainian SSR there were 3 pedagogical, 5 agricultural, 20 industrial Jewish technical schools. Vinnytsia Jewish Pedagogical School, Haisyn Jewish Medical Obstetric School became the influential centers of professional education in Podillia region. For example, in 1930, Vinnytsia Jewish Pedagogical School trained 290 students $^{33}$.

From 1933-1934, the Jewish national education begins to experience a period of decline. Jewish children in the vast majority began to attend Russian or Ukrainian schools. Agitation for the education of children in a Jewish school was considered a dangerous "bias". At first, most Jewish schools were converted into mixed-type schools, and then they ceased to exist at all. From 1938-1939 school year, 2/3 of Jewish children attended Russian schools, and 1/3 the Ukrainian ones. Jewish Soviet national education ceased to exist like others institutions of the national-cultural life. There were only 19 Yiddish schools in the Ukraine in $1939^{34}$. However, they existed in the territories that were included in the Soviet Union during the 1939-1940s. Their Soviet government considered it as an instrument for the sovietisation of new territories ${ }^{35}$.

Oddly enough, occupation during the World War II partially contributed to the restoration of Jewish national education and the upbringing in Podillia. This is about Transnistria, which was in the Romanian occupation zone - an ally of

${ }^{30}$ Вітринська О. Юдейські заклади освіти в контексті радянської політики боротьби 3 релігіею в 1920-30-х роках в Україні // Проблеми історії України: фракти, судження, пошуки. Вип.16. - К., 2007. - С.136.

${ }_{31}$ Гриневич Л., Прилуцький В. Україна: хроніка ХХ століття: Довідкове видання: Рік 19281929. - К., 2007. - C.7.

${ }_{32}$ Константинов В. Еврейское население бывшего СCCP в XX веке (социальнодемографический анализ). - Иерусалим, 2007. - С.83.

33 Якубова Л. Етнічні меншини в суспільно-політичному та культурному житті УСРР: 20-і - перша половина 30-х рр. XX ст. - C.417.

${ }^{34}$ Pinkus B. The Jews of the Soviet Union: the history of a national minority. - P.108.

${ }^{35}$ Halevy Z. Jewish Schools under Czarism and Communism: A Struggle for Cultural Identity. - P.258-267. 
Nazi Germany. Thanks to the self-organization of Jewish communities, bribing Romanian officials in separate ghettos it became possible to provide Jews not only with medical assistance, food, but also partly to restore certain elements of national life.

Thus, due to the activities of the communities in the ghettos of Zhmerynka, Bershad there was organized kindergarten and school, in Tulchyn - a school, and Jewish orphanages were in Bershad, Dzhuryn, Mohyliv-Podilskyi, Murafa, Sokolivka, Tyvriv, and Sharhorod ${ }^{36}$. For example, in the school of the ghetto of Tulchyn, 90 children were studying, where children received not only education, but also learned traditional crafts for Jews and attended music classes. The ghetto of Bershad took care children's home, where were 186 children $^{37}$. In the school of the ghetto of Zhmerynka in 1943 there were 250 students and about 30 teachers. The training took place in Russian. From the fourth grade children studied Romanian and German, and from the fifth - Yiddish and Hebrew ${ }^{38}$.

With the liberation of the territory of Podillia from the invaders, Jewish national education did not exist anymore. Until the mid of 1980s, the Soviet government took the course of destroying any manifestations of the national-cultural life of the Jews. In postwar years, it was restored in ulpans. It was illegal groups for studying Hebrew. Restoration of Jewish national education became possible only with the proclamation of Ukraine's independence and guaranteeing the right to national-cultural autonomy by the Law of Ukraine "On National Minorities" (1992).

At the present stage, Jewish national education develops primarily through a network of public or private educational institutions with Ukrainian or Russian language training. Along with nation-wide academic disciplines, students are learning an in-depth course on Jewish subjects, including: studying the language (mostly Hebrew), the study of Jewish history, acquaintance with Jewish national traditions, and culture ${ }^{39}$. In 2013, in Ukraine were 37 Jewish schools, 60 Sunday schools, 11 kindergartens, 8 yeshivas and 70 ulpans for the study of Hebrew, which was visited by about 10,000 children and adults ${ }^{40}$. However, at the present stage, only one general secondary school of I-III grades "Or Menachem" is functioning in Podillia. This school has been operating since 1992 in Vinnytsia. In the region, the study of the history, language and culture of the Jewish people is predominantly through the system of Sunday schools in Jewish national cultural and religious organizations.

The scientific novelty of the research is to substantiate the role of Jewish national education as a cultural phenomenon, which contributed to the existence of

${ }^{36}$ Винокурова $\Phi$. Національне життя еврейської спільноти на окупованій території Вінницької області, що входила до складу Трансністрії: Огляд архівних джерел. - С.162-163.

37 Там само. - C.163.

38 Мершон Б. Образование и культура в еврейском гетто Жмеринки в период Второй мировой войны // Заметки по еврейской истории: Интернет-журнал еврейской истории, традиции, культуры. - 2004. - №47 [Електронний pecypc]: http://berkovich-zametki.com/ Nomer47/Mirshon1.htm

39 Зеркаль М. Освіта національних меншин України (1990-2000-ні рр.). - С.132.

40 Привалко Д. Єврейське життя в Україні: досягнення, складнощі та пріоритети після падіння комуністичного режиму до 2013 р. / Звіт: Інститут еврейських політичних досліджень (JPR). - London, 2014. - C.499. 
a traditional culture of Jewish communities in the region during a long historical period. The original education of the Jews of the Podillia as a one of the main factor of the national culture has been analyzed from the moment of the emergence of communities to the present time.

Jewish education is a certain cultural phenomenon that has helped the Jews for a long time in conditions of statelessness to preserve the integrity of their people. Education, which was inextricably linked with religion, played a major role in preserving the identity of Jewish communities. An important factor in the development of the Jewish community was the system of traditional education of Jews, built primarily on the upbringing of religiosity and devotion to the traditions and customs of the people.

Until the middle of the 19th century, Jews of Podillia became educated in traditional religious-type educational institutions. National education, religion and traditional family upbringing protected this national minority of assimilation processes. In the Soviet Union, Jewish national education was one of the main forms of existence of the original culture of the Jews of Podillia, especially in the 1920s. The national education and religion became the main forms of national culture among the Jews of Podillia after the proclamation of Ukraine's independence.

\section{REFERENCES}

1. Dotsenko, V. (2014). Yevreiskyi natsionalnyi kulturno-relihiinyi hromadskyi rukh v Ukraini v 1920-ti roky. Hrani, 12, 119-125. [in Ukrainian].

2. Finberh, L. \& Liubchenko, L. (2008). Narysy z istorii ta kultury yevreiv Ukrainy. Vydannia druhe. Kyiv: Dukh i litera. [in Ukrainian].

3. Getmanskiy, E. (2015). Yevreyskoe obrazovanie v Rossiyskoy imperii. Zametki po evreyskoy istorii, 11-12. [Elektronnyi resurs]: http://www.berkovich-zametki.com/2015/ Zametki/Nomer11_12/Getmansky1.php [in Russian].

4. Gitelman, Z. (2001). A Century of Ambivalence: The Jews of Russia and the Soviet Union, 1881 to the Present. Bloomington and Indianapolis: Indiana University Press.

5. Halevy, Z. (1976). Jewish Schools under Czarism and Communism: A Struggle for Cultural Identity. Foreword by George Z. F. Bereday. New York: Springer Publishing Company.

6. Hrynevych, L. (2004). Yevreiske natsionalno-kulturne vidrodzhennia 1920-kh - 1930kh rr. v USRR u "prokrustovomu lozhi» bilshovytskoi ideolohii. Problemy istorii Ukrainy: fakty, sudzhennia, poshuky: Mizhvid. zb. nauk. pr., 12, 225-233. [in Ukrainian].

7. Hrynevych, L. \& Prylutskyi, V. (2007). Ukraina: khronika XX stolittia: Dovidkove vydannia: Rik 1928-1929. Kyiv: Instytut istorii Ukrainy NAN Ukrainy. [in Ukrainian].

8. Komarnitskyi, O. (2003). Yevreiska natsionalna shkola v mistechkakh Pravoberezhnoi Ukrainy 1917-1918 rr. Osvita, nauka i kultura na Podilli: Zbirnyk naukovykh prats, 139-149. Kamianets-Podilskyi: Oiium. [in Ukrainian].

9. Konstantinov, V. (2007). Evreyskoye naseleniye byvshego SSSR v XX veke (sotsialnodemograficheskiy analiz). Ierusalim. [in Russian].

10. Miller, A. (2006). Imperiya Romanovykh i natsionalizm: Esse po metodologii istoricheskogo issledovaniya. Moskva: Novoe literaturnoe obozrenie. [in Russian].

11. Pinkus, B. (1998). The Jews of the Soviet Union: the history of a national minority. Cambridge: Cambridge University Press. 
12. Pryvalko, D. (2014). Yevreiske zhyttia v Ukraini: dosiahnennia, skladnoshchi ta priorytety pislia padinnia komunistychnoho rezhymu do 2013 roku / Zvit. Instytut yeureiskykh politychnykh doslidzhen (JPR). London: Institute for Jewish Policy Research (JPR). [in Ukrainian].

13. Schulman, E. (1971). A History of Jewish Education in the Soviet Union. New York: KTAV Publishing House.

14. Shternshis, A. (2006). Soviet and Kosher. Jewish Popular Culture in the Soviet Union, 1923-1939. Bloomington and Indianapolis: Indiana university press.

15. Shytiuk, M. \& Shchukin, V. (2008). Yevreiske naselennia Khersonskoi hubernii v $X I X$ - na pochatku XX st. Mykolaiv: Vydavnytstvo Iryny Hudym. [in Ukrainian].

16. Vitrynska, O. (2007). Yudeiski zaklady osvity v konteksti radianskoi polityky borotby z relihiieiu v 1920-30-kh rokakh v Ukraini. Problemy istorii Ukrainy: fakty, sudzhennia, poshuky, 16, 129-141. [in Ukrainian].

17. Voskoboynik, D. (2002). The History of Jews in Proskurov, Ukraine. Schenectady: Union college.

18. Vynokurova, F. (2005). Natsionalne zhyttia yevreiskoi spilnoty na okupovanii terytorii Vinnytskoi oblasti, shcho vkhodyla do skladu Transnistrii: Ohliad arkhivnykh dzherel. Druha svitova viina $i$ dolia narodiv Ukrainy: Materialy Vseukrainskoi naukovoi konferentsii (Kyiv, 23-24 chervnia 2005 r.), 156-164. Kyiv: Sfera. [in Ukrainian].

19. Yakubova, L. (2006). Etnichni menshyny $v$ suspilno-politychnomu ta kulturnomu zhytti USRR: 20-i-persha polovyna 30-kh rr. XX st. Kyiv. [in Ukrainian].

20. Zerkal, M. (2013). Osvita natsionalnykh menshyn Ukrainy (1990-2000-ni rr.). Ukrainskyi istorychnyi zhurnal, 2, 121-135. [in Ukrainian].

\section{ОЛЕКСАндР ДАНИЛЕНКО}

доктор історичних наук, професор кафедри історії світового українства, Київський національний університет ім. Т.Шевченка (Київ, Україна), ovd@ua.fm

\section{ВАЛЕРІЙ КОНОНЕНКО}

доктор історичних наук, доцент, доцент кафедри правових наук та фрілософрї̈, Вінницький державний педагогічний університет ім. М.Коцюбинського (Вінниця, Україна), valeriy_kononenko@ukr.net

\section{НАЦІОНАЛЬНА ОСВІТА У ЗБЕРЕЖЕННІ САМОБУТНОСТІ ЄВРЕЙСЬКИХ ГРОМАД ПОДІЛЛЯ}

Визначено роль національної освіти у збереженні самобутньої культури євреїв Поділля. Розглядаеться місие традииійної освіти в контексті національної ідентичності єврейських гролад регіону в порівнянні з ббункиіонуваннял національної освіти євреїв загалол в Україні. Методологія дослідження базуеться на використані порівняльно-історичного, статистичного, структурно-фбункиіонального, терлінологічного методів зі врахуванням аксіологічного (иіннісного) підходу, що дав змогу розглядати єврейську національну освіту як салодостатне утворення з систелою певних иінностей, важливих для фбункиіонування національної культури євреїв. Наукова новизна полягає в обтрунтуванні провідної ролі єврейськоӥ національної освіти як культурного фбенолена у збереженні салобутньої культури єврейських громад регіону впродовж тривалого історичного періоду. Зазначено, що на території 
Поділля сфборлувалася одна з найпотужніших єврейських громад Східної Європи, що представляла собою субетнос - ашкеназі. Євреї Поділля, які тривалий період жили в уловах дискрилінаційної політики, спрялованої на знищення основ національного життя, зуміли зберегти свою ідентичність і культуру. До включення територї Поділля до складу Російської ілперії серед місиевих євреїв зберігалася традииійна національна систела освіти. Вона базувалася на міцному зв'язку навчання з релігією, традиціяли єврейського народу, а навчальних закладів - з органами місцевого самоврядування євреїв (кагалами). Століттяли єврейська спільнота зберігала свою національну самобутність, уникала повної асиліляиї. Разол із релігією освіта захищала евреїв від втрати елементів національно-культурного життя та національних особливостей життя гролади. Російська ілперська влада намагалася заохотити євреїв до навчання у загальнодержавних закладах освіти, сподіваючись таким чином подолати їх культурну відокремленість, соборлувати лояльність до імперії. Проте переважна більшість євреїв Поділля продовжували традииійно навчатися у хедерах і таллуд-торах. Нові перспективи для розвитку національної освіти відкрилися з 1917 р., після Лютневої буржуазно-делократичної революиї̈ в Російській імперії. Украӥна, яка сала боролася за незалежність, була лояльною до реалізації євреяли права на національно-культурну автонолію. Розвитку освіти сприяли декрети Української Народної Республіки (1917-1920рр.). Центральне місие в підтримиі світської національної освіти відігравали культурно-просвітницькі товариства "Тарбут" $i$ "Культура-Ліга". У ией час кількість національних закладів освіти євреїв Поділлі неухильно збільшувалася. Радянський уряд узяв курс на знищення релігійних навчальних закладів $і$ витіснення івриту як мови навчання. Одночасно єврейські національні школи з мовою навчання їдиш розглядалисяяк елелент радянізаціїєвреїв. Тож на Поділлі в період "коренізації» збільшилася кількість національних єврейських шкіл, закладів профбесійної та спеціальної освіти. Проте з кіния 1940-х рр. органи партійної й державної влади запровадили курс на асиліляцію та знищення національного життя євреїв. Останні в ретіоні національні світські заклади освіти було закрито наприкіниі 1930-х рр. Із проголошеннял незалежності України з'явилися нові можливості для відновлення національної освіти єврейських громад Поділля. У ией час освіта й релігія стали основнили елелентали відновлення та збереження національно-культурного життя єврейського народу. Проте через різке зменшення кількості населення на сьогодні в ретіоні діє лише одна приватна загальноосвітня єврейська школа, а національна освіта гролади впроваджуеться переважно через систелу недільних шкіл $i$ позакласних заходів при культурних, релігійних організаціях. Зазначаеться, шо єврейська національна освіта є певним культурнил та соціальнил фбеноленом, якии дополіг евреял тривалий час в уловах бездержавності зберегти иілісність свого народу. Сале освіта, що була нерозривно пов'язана з релігією, відіграла чи не основну роль у збереженні своєрідності єврейських громад Поділля.

Ключові слова: євреї, Поділля, національна освіта, салобутність, національна культура. 